\title{
Description of a Small-headed Gnathiid Isopod (Crustacea), Gnathia capitellum sp. nov., from Coastal Japan
}

\author{
Yuzo Ota ${ }^{1,4}$, Hisanori Kohtsuka ${ }^{2}$, and Katsuhiko Tanaka ${ }^{3}$ \\ ${ }^{1}$ San'in Kaigan Geopark Museum of the Earth and Sea, 1794-4 Makidani, Iwami-cho, Tottori 681-0001, Japan \\ E-mail:yota1164@gmail.com \\ ${ }^{2}$ Misaki Marine Biological Station, Graduate School of Science, The University of Tokyo, \\ 1024 Koajiro, Misaki, Miura, Kanagawa 238-0225, Japan \\ ${ }^{3}$ Department of Marine Biology, School of Marine Science and Technology, Tokai University, \\ 3-20-1 Orido, Shimizu, Shizuoka 424-8610, Japan \\ ${ }^{4}$ Corresponding author
}

(Received 2 October 2020; Accepted 27 June 2021)

http://zoobank.org/7B906E72-9860-4DE3-9DF9-EB15E2902376

\begin{abstract}
Adult male and larva of Gnathia capitellum sp. nov. (Crustacea: Isopoda: Gnathiidae) are described. The specimens were laboratory-reared larvae that infested host fishes collected by longline fishing in a coastal bay of Izu Peninsula and adult males found in dredge samples from shallow water (depth: 11-12 m) of Miura Peninsula, central Japan. Adult males of G. capitellum sp. nov. were easily distinguished from the other species of Gnathia Leach, 1814 from around the world by the small oval head and the inner margin of pylopod without plumose setae. Most other Gnathia species have a large rectangular head and plumose setae present on the article 1 of pylopod. Appearance of the adult male resembles the genus Afrignathia Hadfield and Smit, 2008 rather than Gnathia but Afrignathia has maxilla 1 which is absent in all known male gnathiids in the world including G. capitellum sp. nov. Fish parasitic larva of G. capitellum sp. nov. is also described herein. This larva closely resembles larvae of the genus Gnathia, but can be distinguished from the other Gnathia species by the remarkably oval-shaped basis in pereopods 2-4.
\end{abstract}

Key Words: Gnathiid, dredge, ectoparasite, Platycephalus sp., Takifugu snyderi.

\section{Introduction}

The isopod family Gnathiidae is characterized by nipperlike or forceps-like mandibles in male adults, while adult females lack mandibles and have swollen bodies to brood eggs. Gnathiid larvae are generally ectoparasites of fishes. Their mouthparts show needle-like shapes to pierce the skin of their host fish. They are often called praniza larvae for their swollen and non-segmented thorax (pereonite 3-5), engorged due to the ingested fish's body fluid, and zuphea larvae with a segmented thorax before ectoparasitism (Smit and Davies 2004; Tanaka 2007). The taxonomy of gnathiids has been traditionally based on the morphology of adult males which present more highly diverse morphologies than those of females and larvae (Monod 1926; Smit and Davies 2004; Tanaka 2007). Cohen and Poore (1994) analyzed gnathiid phylogeny at a genus level using 72 characters of 95 species and proposed 10 gnathiid genera. Subsequently, two genera have been described (Tanaka 2005; Hadfield and Smit 2008). Currently, Gnathiidae includes 12 genera and approximately 200 species from around the world (Boyko et al. 2008 onwards). In waters adjacent to Japan, six genera and 38 species have been recorded (Ota 2014, 2015). In this study, larvae of gnathiids ectoparasitizing host fishes were reared in the laboratory until maturation and adult specimens of the species were also sampled by dredge. As the combination of mor- phological features does not correspond to any known species, we describe the present species as a new species.

\section{Materials and Methods}

On 4 November 2011, we collected gnathiid larvae from the host fishes caught by longline fishing in Nabeta Bay, Shimoda City, Izu Peninsula, central Japan $\left(34^{\circ} 66^{\prime} 45.4^{\prime \prime} \mathrm{N}\right.$, $\left.138^{\circ} 94^{\prime} 12.4^{\prime \prime} \mathrm{E}\right)$. Some individuals were fixed and preserved in $70 \%$ ethanol for morphological observations, and others were reared in the laboratory to obtain adult specimens. On 14 March 2013 and 16 October 2014, we collected adult specimens from dredge samples at the depth of 3-11 $\mathrm{m}$ in Koajiro Bay, Miura City, Miura Peninsula, central Japan $\left(35^{\circ} 16^{\prime} 33.8^{\prime \prime} \mathrm{N}, 139^{\circ} 62^{\prime} 42.3^{\prime \prime} \mathrm{E}\right)$ and gnathiid specimens were preserved in $70 \%$ ethanol.

Appendages of some specimens were removed with sharpened tungsten needles and mounted in CMCP-10 High Viscosity Mountant (Polyscience, Warrington, Pennsylvania, U.S.A.). Observations were made using a phase-contrast light microscope, and drawings were made using a camera lucida. Some specimens were air-dried from hexamethyldisilazane (HMDS) and studied with a scanning electron microscope (SEM). Total length of body was measured between tip of mandibles and pleotelson. Voucher material is deposited in the National Museum of Nature and Science, Tsukuba, 

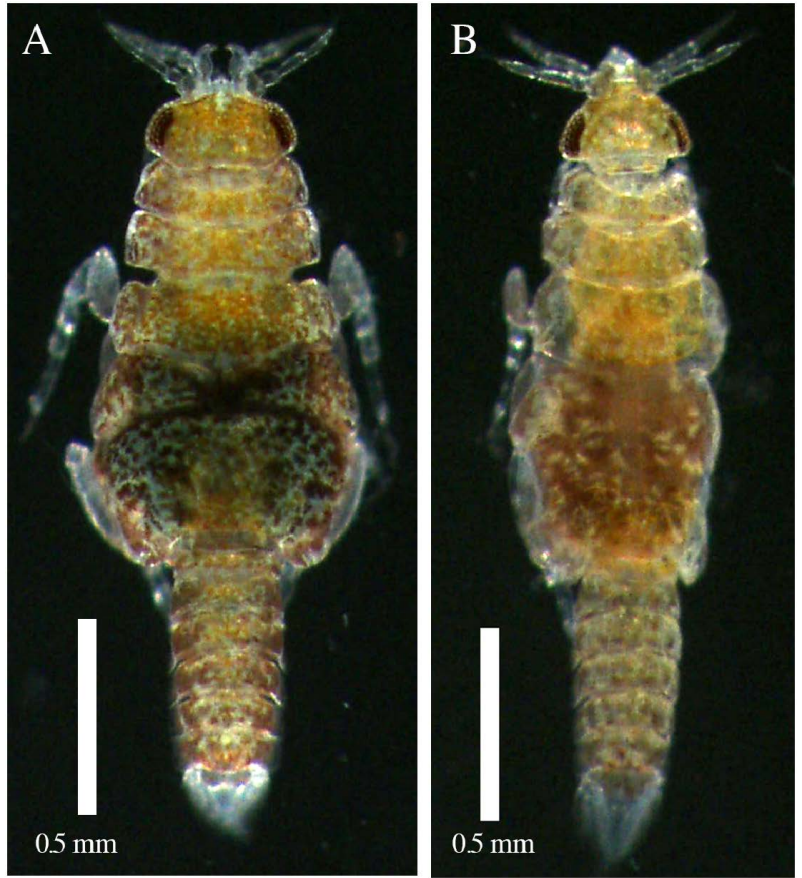

Fig. 1. Photograph of live specimens of Gnathia capitellum sp. nov. A, Male adult in dorsal view; B, third zuphea larva in dorsal view (Non type specimens but collected from the same host as the holotype).

Japan (NSMT). The terminology for gnathiid morphology follows usage by Cohen and Poore (1994), Smit and Davies (2004), and Wilson et al. (2011). The scientific and Japanese names of host fishes follow details given by Nakabo (2013).

Family Gnathiidae Leach, 1814

Genus Gnathia Leach, 1814

Gnathia capitellum sp. nov.

[New Japanese name: Kogashira-umi-kuwagata] (Figs 1-7)

Type material. Holotype: adult male (NSMT-Cr 28254), $2.17 \mathrm{~mm}$, molted from praniza larva that infested Platycephalus sp. 2 of Nakabo (2013) caught by longline fishing, off Nabeta Bay, 4 November 2011, coll. Y. Ota. Paratypes: two third stage praniza larvae (NSMT-Cr 28255), $2.49,3.14 \mathrm{~mm}$, from same host and locality as holotype; two adult males (NSMT-Cr 28256), 2.06, $2.14 \mathrm{~mm}$, molted from praniza larvae that infested Takifugu snyderi (Abe, 1988) caught by longline fishing, off Nabeta Bay, 4 November 2011, coll. K. Tanaka; two adult males (NSMT-Cr 28257), 2.03, $2.14 \mathrm{~mm}$, dredge, Koajiro Bay, $11-12 \mathrm{~m}$ depth, 14 March 2013, coll. H. Kohtsuka; two adult males (NSMT-Cr 28258) , 2.28, $2.54 \mathrm{~mm}$, dredge, Koajiro Bay, muddy substratum, 3 m depth, 16 October 2014, coll. H. Kohtsuka.

Locality. Nabeta Bay, Izu Peninsula (type locality) and Koajiro Bay, Miura Peninsula, Japan.

Etymology. The specific name "capitellum" was derived from the Latin meaning "small head".

Description of adult male. Head (Figs 2B, 3A-C) oval, length ca. 1/8 of body length, width about 1.7 times of length, with concave posterior margin; dorsal sulcus shallow, narrow in anterior part; dorsal surface covered with sensory pits (Fig. 2A). Eyes well developed, occupying about 0.6 times of head length; paraocular ornamentation not developed; supraocular lobe not prominent. Frontal border centrally concave with three processes: mediofrontal process dentate; two superior frontolateral processes slightly protruded.

Pereonites (Fig. 3A) widest in pereonite 5. Pereonites 1-4 covered with sensory pits and pereonites 5-7 not covered; cuticula of posterior parts not well developed (Fig. 2A). Pereonite 1 short, not fused with head, not reaching lateral margins of head. Pereonite 2 obviously concave in anterior margin. Pereonite 3 rectangular shape. Pereonite 4 oval shape with convex in posterior margin. Pereonite 5 rectangular with areae laterales. Pereonite 6 longer than pereonite 5; lobi laterals not visible. Pereonite 7 short, narrow, overlapping pleonite 1. Pleonites 1-5 (Fig. 3A) with small setae on lateral margins. Epimera prominent in pleonites 2-4. Pleotelson (Fig. 3E) triangular, with blunt apex, with pair of setae; broad ridge visible, bearing three pairs of setae on dorsal surface.

Mandible (Fig. 3C, D), length less than $1 / 2$ of head length; apex curved inward; dentate blade occupies ca. 3/4 of mandible length; basal neck, erisma prominent; mandibular seta, incisor, armed carina, internal lobe lacking. Antennule (Fig. 3F) composed of three peduncular, four flagellar articles; one, one, two penicillate setae on distal margins of peduncles 1, 2, 3, respectively; articles 2-4 each with aesthetasc; article 4 terminating in simple seta. Antenna (Fig. $3 \mathrm{G}$ ) with four peduncular, seven flagellar articles; large seta on peduncle 3 , penicillate seta on peduncles 3 , 4, respectively; 0-3 setae present on each distal margin of flagellar articles 1-7. Maxilla 2 reduced, fused with head (Fig. 2C). Maxilliped (Fig. 4A) composed of basis, four palp articles; endite absent; palp articles 2, 3 longer than articles 1, 4; palp articles 1-4 with two, four, four, one plumose setae on external margin, respectively; three simple setae on internal margin of article 4. Pylopod (Fig. 4B) with three articles; article 1 semicircular, without both areolae, plumose setae, bearing three simple setae subdistally; article 2 same length as article 3; article 3 with simple seta.

Pereopods (Fig. 5A-E), pereopods 2, 3 entirely shorter, thicker than pereopods 4-6; ischium, merus, carpus of pereopods 2-4 covered with tubercles. Penes (Fig. 4C) composed of two contiguous, non-prominent papillae. Pleopodal basis (Fig. 5F, G) with single seta, two coupling hooks on distolateral, distomesial margins, respectively; pleopod 1, 2 rami with 8 or 9 plumose setae on exopod, 7 or 8 plumose setae on endopod; pleopod 2 lacking appendix masculina. Uropodal rami (Fig. 3E) subequal in length, not extending beyond apex of pleotelson; exopod with nine simple setae on external margin; endopod with eight simple setae on external, internal margins, five penicillate setae on dorsoexternal surface.

Size of adult males. 2.06-2.54 mm (between frontal border and pleotelson, mean $\pm S D, 2.19 \pm 0.17 \mathrm{~mm} ; \mathrm{n}=7$ ). Adult males molted after six or seven days after detaching from their host. 

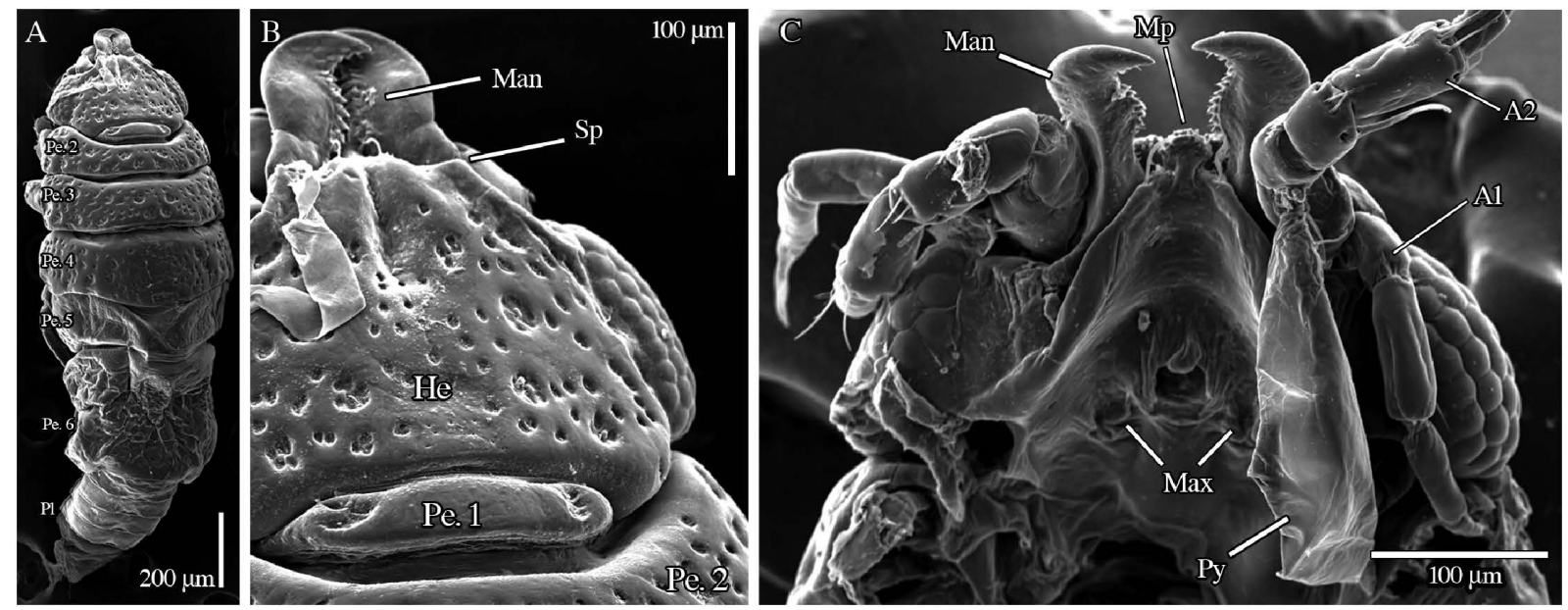

Fig. 2. Male adult of Gnathia capitellum sp. nov. under scanning electron microscopy (paratype, NSMT Cr-28258). A, Whole body in dorsal view; B, right side of head in dorsal view; C, head in ventral view. Abbreviations: Pe, pereonite; Pl, pleonite; Man, mandible; He, head; Max, maxilla 2; Py, pylopod; Mp, mediofrontal process; Sp, superior frontolateral process; A1, antennule; A2, antenna.

Pigmentation of adult males. (Fig. 1A). Body light brown; digestive organs green due to congealed host blood; brown spots often remaining in fixed specimens.

Adult female characters. Unknown.

Description of third larva. Head (Fig. 6A, B) semicircular, length ca. $3 / 5$ of width. Clypeus pentagonal with slightly concave in anterior margin. Eyes occupying ca. 7/10 of maximum length of head. Pereonite 1 (Fig. 6A) short. Pereonites 2 concave on anterior margin, with one seta on lateral margin. pereonite 3 closely similar to, slightly larger than pereonite 2. Segments of pereonites 4-6 visible, slender in zuphea larva (Fig. 1B), fused, swollen by fish's body fluid in praniza larva (Fig. 6A); lateral shields of pereonites 4, 5 visible in dorsal view, elliptical. Pereonite 7 reduced, overlapping pleopod 1. Pleonites 1-5 (Fig. 6A) almost same length, epimera prominent in pleonite 5. Pleotelson (Fig. 6C) with broad ridge and three pairs of setae on dorsal surface and apex. Apex not acute.

Both antennae (Fig. 6D, E) almost same shapes, setations as those of male adult; peduncle 3 of antenna lacking distomesial large seta (Fig. 6E). Gnathopod (=pereopod 1) (Fig. 6F) smaller than pereopods; pectinate scales covered with inner margins of basis, ischium, carpus; carpus reduced. Maxilliped (Fig. 6G) composed of two basal, two palp articles; basal article 2 with endite and single coupling hook on inner margin; apex of palp 1 with five teeth and seta; apex of palp 2 with five setae and two spines. Mandible (Fig. 6H) with seven teeth. Maxillule (Fig. 6I) with three teeth on apex. Paragnath (Fig. 6J) stylet-like with groove on inner margin.

Pereopods (Fig. 7A-E) stouter, shorter than those of male adult. Basis of pereopods 2-4 oval shape. Exopod of pleopods (Fig. 7F) fan-shaped with eight or nine plumose setae; endopod oval, with seven or eight plumose setae on distal margins. Uropod (Fig. 6C) not reaching apex of pleotelson; exopod with five simple setae externally, four plumose setae internally; endopod with three simple setae externally, four simple setae dorsally, four plumose setae internally.
Size of third larvae. $2.49,3.14 \mathrm{~mm}$.

Pigmentation of third larva. Body light brown with brown spots, often remaining in fixed specimens (Fig. 1B).

Host. Platycephalus sp. 2 of Nakabo (2013) [Japanese name: Magochi] (type host) and Takifugu snyderi (Abe, 1988) [Japanese name: Shousai-fugu]. Site of infection: skin.

Remarks. The morphologies of our specimens having a small and oval-shaped head resembles the "premale" stage reported only in the Antarctic species, Caecognathia calva (Vanhöffen, 1914). The premale stage is an intermediate stage between praniza larva and adult male defined by a broader head than that of praniza larva (Wägele 1987, 1988). This stage has not been reported in the other gnathiid species for which the life cycle has been studied (Mouchet 1928; Klitgaard 1991; Tanaka and Aoki 1998; Smit et al. 2003; Hadfield et al. 2009; Ota et al. 2012; Chong et al. 2015). Praniza larvae we reared in the laboratory metamorphosed into male adults in six or seven days after collection, and the male did not molt into the next stage for about two months (Ota, personal observation). The period is enough to mature after hatching for male gnathiids in temperate regions. For example, Elaphognathia cornigera (Nunomura, 1992), of which the study site was the same as the locality of our specimens needed 52 days to reach male adults after eclosion (Tanaka 2003). Smit et al. (2003) concluded that 62 days were required to complete the cycle from egg to egg in Gnathia africana Barnard, 1914. Furthermore, the mean duration from eclosion to the molt to adult was approximately 39 days in males and 51 days in females in E. discolor (Nunomura, 1988) (Tanaka and Nishi 2011). Wägele (1988) reported third stage larvae of C. calva metamorphosed into male adults via premale stage within six weeks. However, the life cycle of the Antarctic C. calva was assumed to take four to five years (Wägele 1988), and the premale period may be not long compared to the lifespan. Therefore, our observation during two months may be sufficient to examine the presence/absence of a premale stage in our specimens. In the premale stage in C. calva, dorsal 


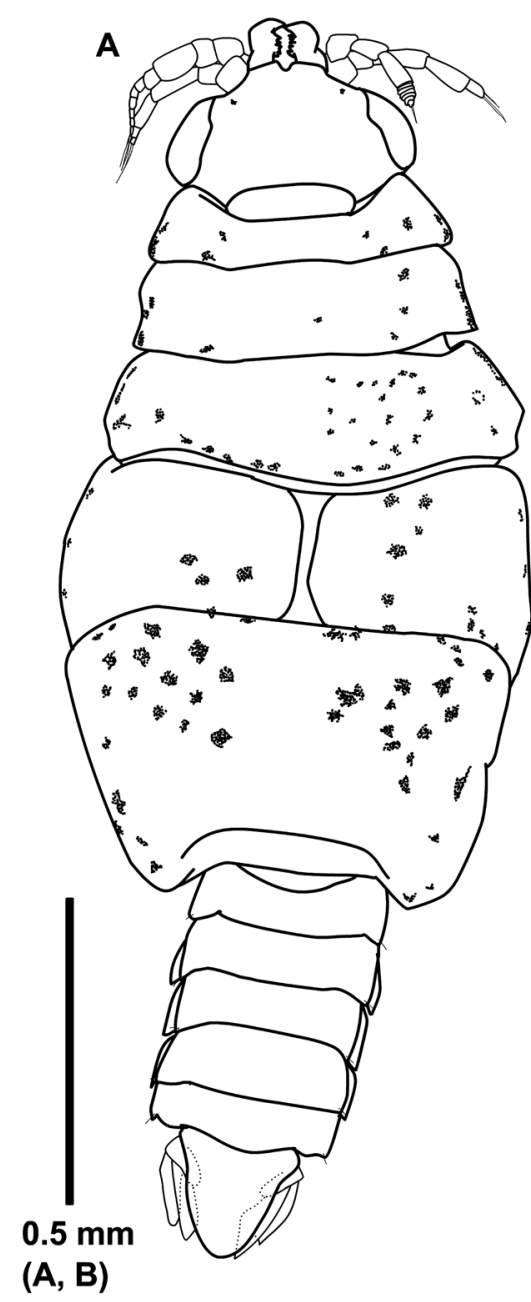

(A, B)

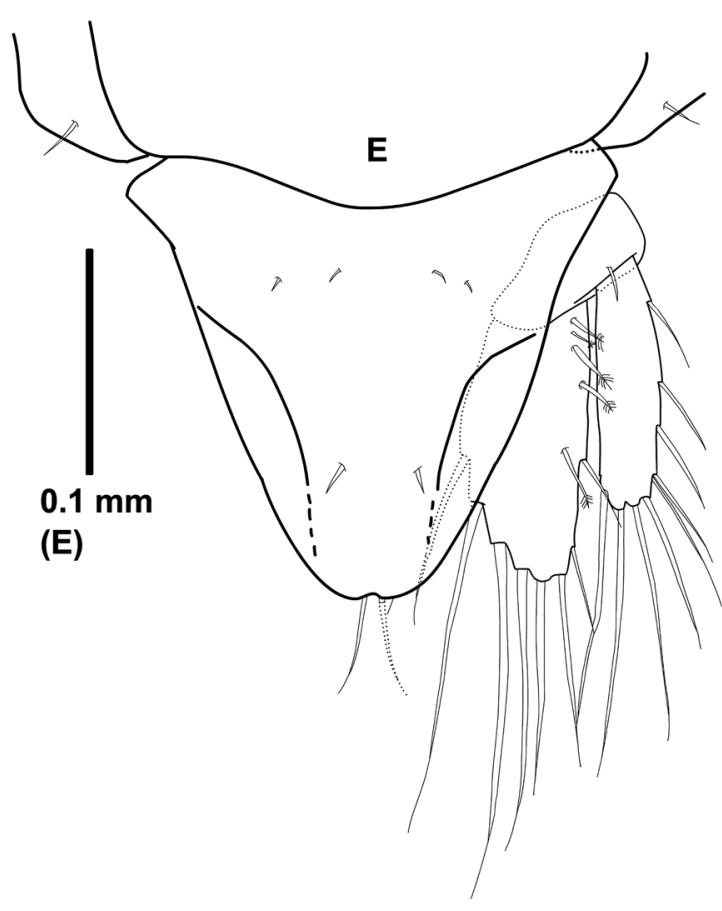

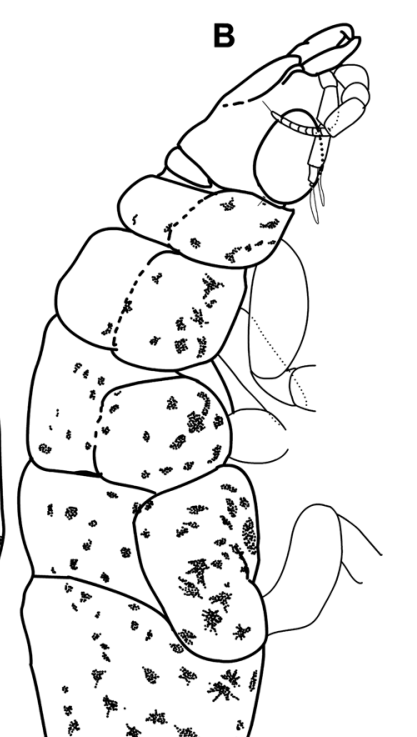
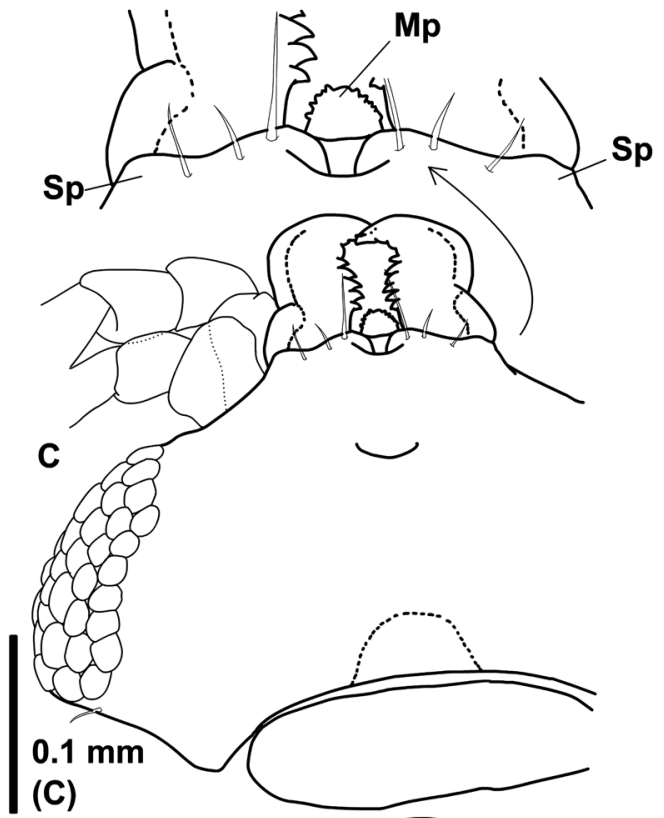

$\mathrm{mm}$

(D)

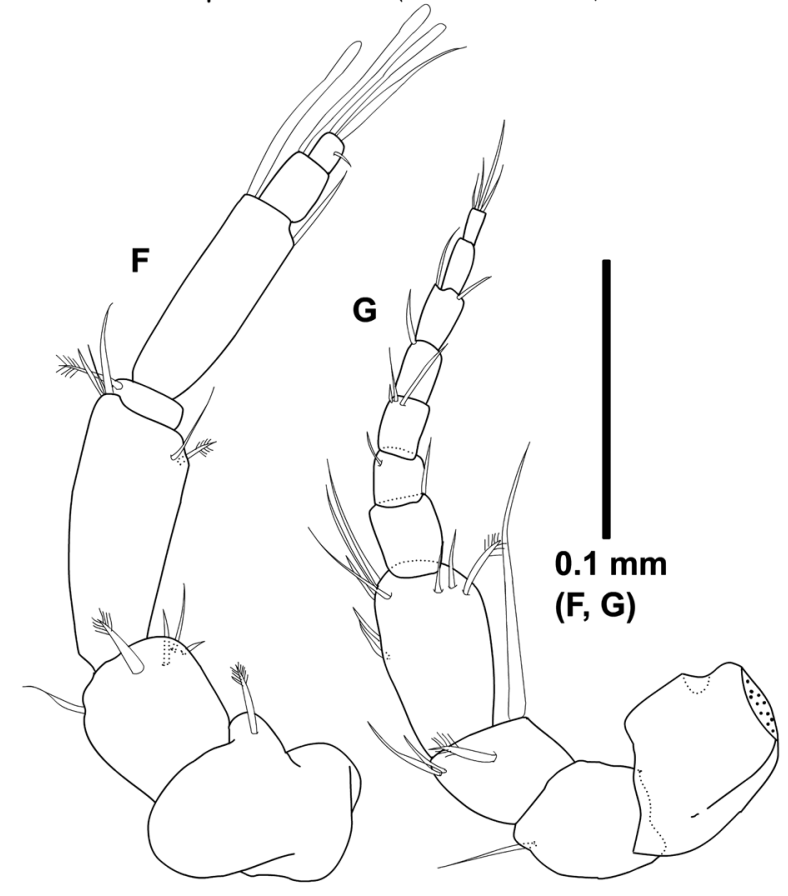

Fig. 3. Male adult of Gnathia capitellum sp. nov. (holotype, NSMT Cr-28254). A, Body in dorsal view; B, body in lateral view; C, head in dorsal view; D, head in ventral view; E, pleotelson in dorsal view; F, left antennule; G, left antenna. Abbreviations: Mp, mediofrontal process; Sp, superior frontolateral process. 


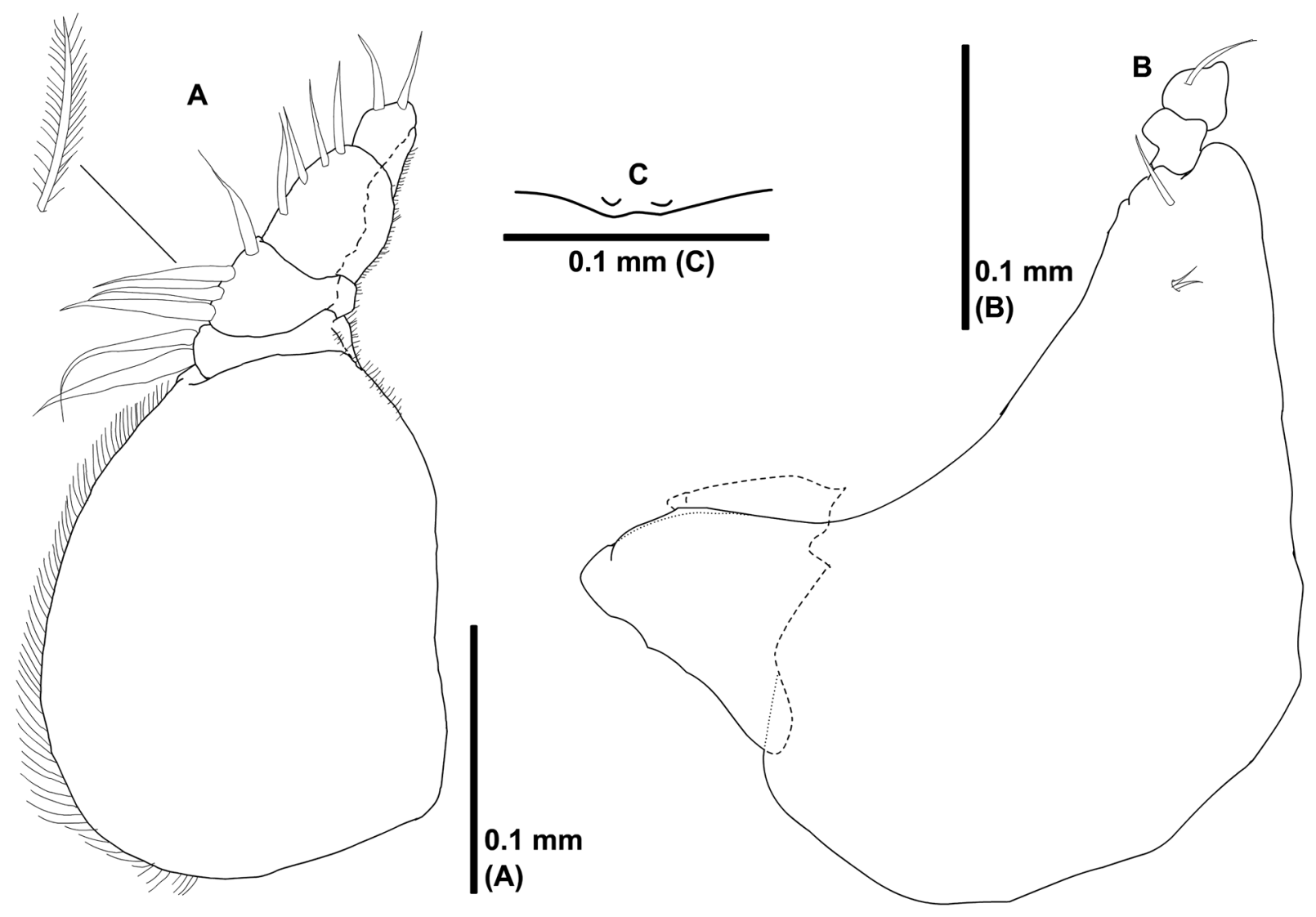

Fig. 4. Male adult of Gnathia capitellum sp. nov. (holotype, NSMT Cr-28254 for B, C; paratype, NSMT Cr-28258 for A). A, Right maxilliped; B, left pylopod; C, penes.

pereonite 5 (called as sixth thoracic segment in the original description) has a dilatable membrane and no chitinized tergite, and the segment is swollen (Wägele 1987). In mature male in C. calva, the membrane on pereonite 5 shrunk with a chitinized tergite (cf. Wägele 1987: fig. 12B). Pereonite 5 of a male G. capitellum had a shrunk membrane as well as a well-chitinized tergite. Thus, our specimens were considered not to have a premale stage, and males obtained in this study were fully matured males.

The general appearance of our specimens closely resembles the monospecific genus Afrignathia Hadfield and Smit, 2008 than the genus Gnathia. Afrignathia multicavea Hadfield and Smit, 2008 has an anterior body surface covered with sensory spots, body width widest in pereonites 5 and 6 oval head with compound eyes and dorsal sulcus, no paraocular ornamentation, a centrally concave frontal border, short mandibles with dentate blade, and an inner margin of pylopod without plumose setae (Hadfield and Smit 2008); and these characteristics are shared with our specimens. However, A. multicavea has a maxilla 1 which is absent in all other known male gnathiids around the world including our specimens.

In the family Gnathiidae, four genera, Caecognathia Dollfus, 1905, Elaphognathia Monod, 1926, Gnathia, and Tenerognathia Tanaka, 2005, are known to have two- or three- articled pylopod as in the present species (Cohen and Poore 1994; Tanaka 2005). The genus Caecognathia is defined by having a rounded frontal border without frontal process and head lacking paraoccular ornamentation and dorsal sulcus (Cohen and Poore 1994). Our specimens have three frontal processes and dorsal sulcus. The genus Elaphognathia is defined by an excavated frontal border and long mandibles without a dentate blade (Cohen and Poore 1994). The present new species has a centrally concave frontal border and small mandibles. The genus Tenerognathia is defined by eyes occupying the whole of the side of head, narrow L-shaped pylopods and weakly chitinized pereonites (Tanaka 2005). In the present new species, eyes are ordinary, pylopods are wide and pereonites are well-chitinized. Therefore, our specimens are separated from Caecognathia, Elaphognathia, and Tenerognathia.

The genus Gnathia is defined by 1) a frontal border has mediofrontal processes, 2) head may possess paraoccular ornamentation and/or a dorsal sulcus, 3 ) frontal border of cephalosome is not deeply excavated, and 4) mandibles are not elongated (Cohen and Poore 1994). Our specimens have a centrally concave frontal border of cephalosome with three frontal processes, a dorsal sulcus on the head, and short mandibles (Fig. 3C). These characteristics correspond to be a species in the genus Gnathia.

In the genus Gnathia, over 130 species have been recorded from around (Boyko et al. 2008 onwards). our specimens have unique characteristics in this genus because its small oval head and the inner margin of pylopod which lacks plumose setae. Gnathia prolasius Cohen and Poore, 1994, G. stigmacros Cohen and Poore, 1994, and G. limicola Ota 


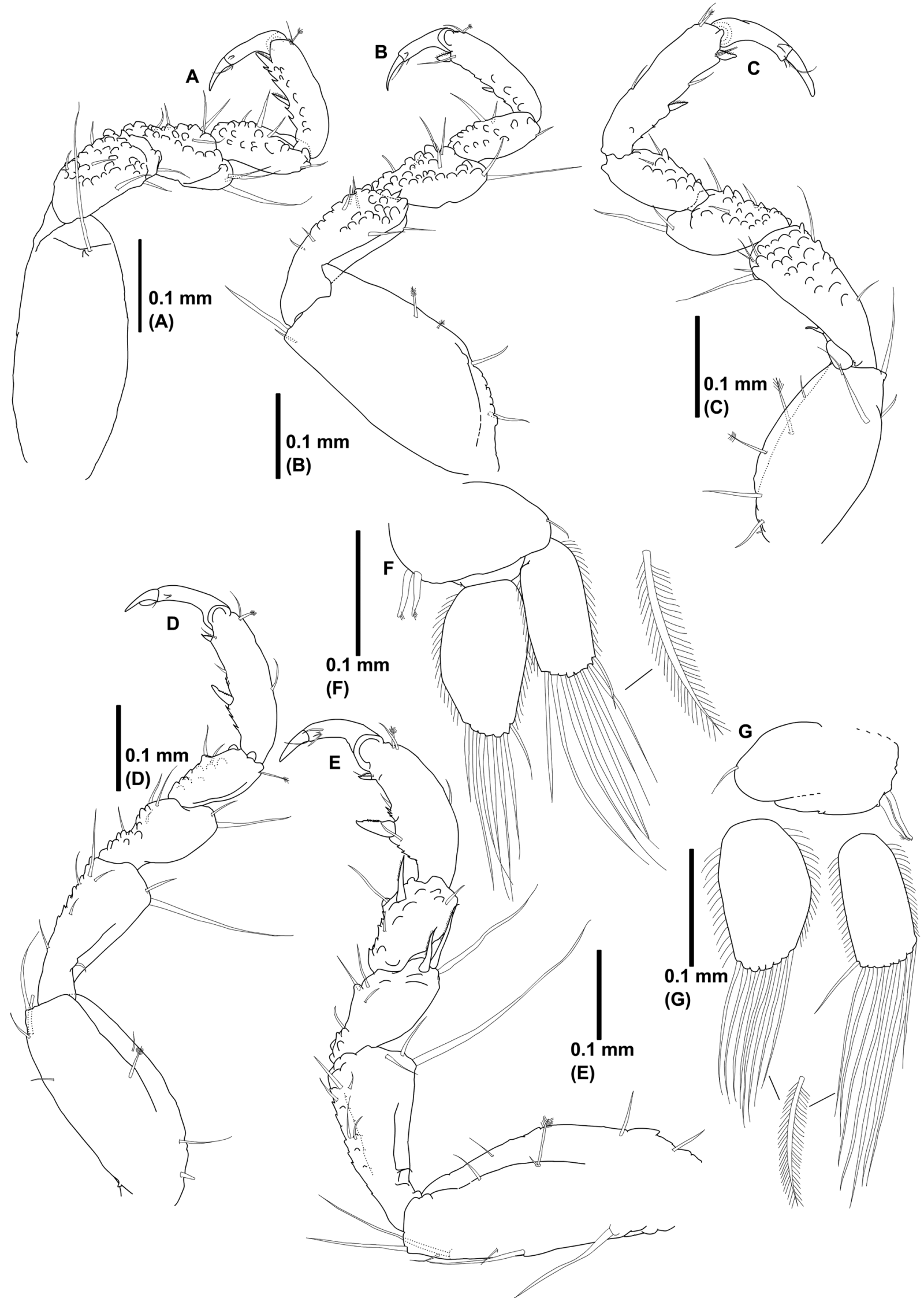

Fig. 5. Male adult of Gnathia capitellum sp. nov. (holotype, NSMT Cr-28254). A, Left pereopod 2; B, left pereopod 3; C, left pereopod 4; D, left pereopod 5; E, left pereopod 6; F, left pleopod 1; G, left pleopod 2. 


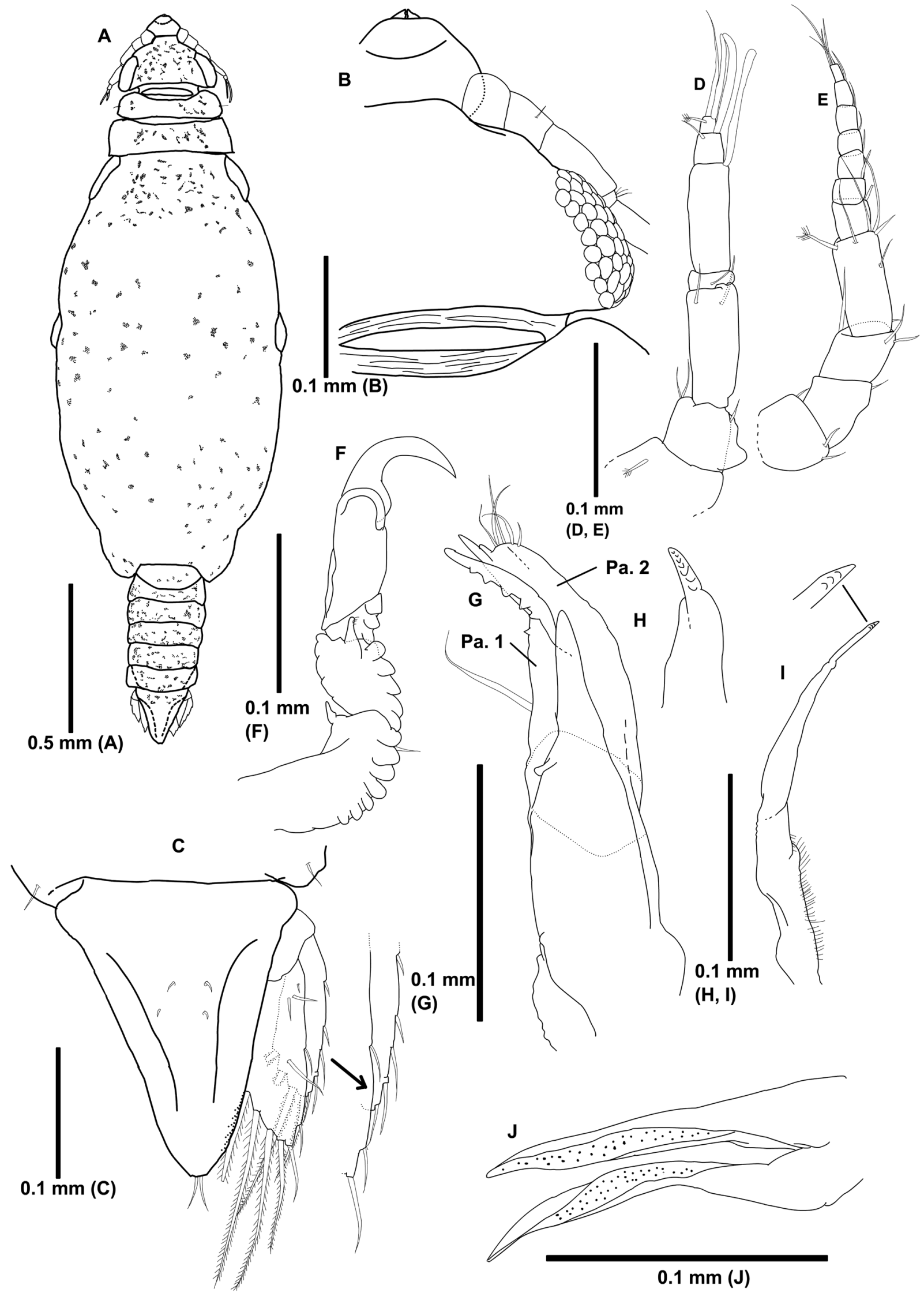

Fig. 6. Third praniza larva of Gnathia capitellum sp. nov. (paratype, NSMT Cr-28255). A, Body in dorsal view; B, head in dorsal view; C, pleotelson in dorsal view; D, left antennule; E, left antenna; F, left gnathopod; G, left maxilliped; H, mandible; I, paragnath; J, a pair of maxillule. 

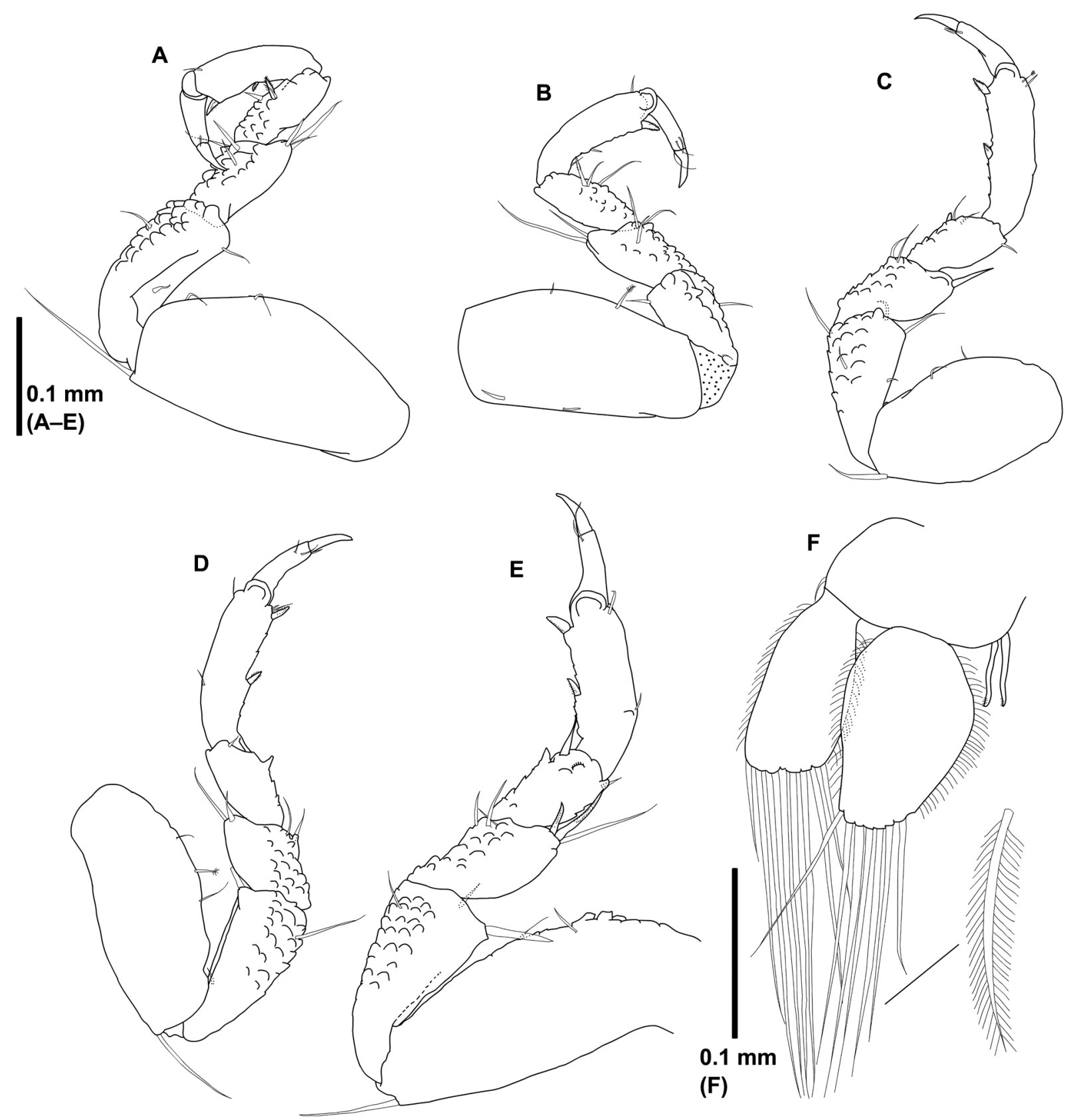

Fig. 7. Third praniza larva of Gnathia capitellum sp. nov. (paratype, NSMT Cr-28255). A, Left pereopod 2; B, left pereopod 3; C, left pereopod 4; D, left pereopod 5; E, left pereopod 6; F, left pleopod 3.

and Tanaka, 2007 also lack plumose setae on pylopods. However, the head shapes are rectangular in G. prolasius and G. stigmacros or pentagonal in G. limicola (Cohen and Poore 1994; Ota et al. 2007). Thus, our specimens were identified as a new species of Gnathia.

On the contrary of adult male morphology above mentioned, larval morphologies of G. capitellum sp. nov. were remarked here. Among Gnathia species around the world, G. capitellum sp. nov. is most similar to G. marleyi Farquharson, Smit, and Sikkel, 2012. Gnathia marleyi is easily distinguished from G. capitellum sp. nov. by compound eyes occupying almost same length as head, triangular pleotelson with a slightly concave lateral margin, and uropodal endopod extending to approximately same length as apex of pleotelson (Farquharson et al. 2012). In contrast, eyes occupy ca. 7/10 of length of head, lateral margin of pleotelson is straight, and both uropodal rami do not extend to apex of pleotelson in G. capitellum sp. nov.

Of 24 Gnathia species known from Japanese coastal and adjacent waters, larval morphologies have been described in 12 species (Nunomura and Honma 2004; Tanaka 2004; Ota et al. 2007; Coetzee et al. 2008, 2009; Ota and Hirose 2009a, b; Ota 2011, 2014, 2015). Most of the species (10) have been reported from elasmobranch fishes. Larvae of these species (4-13 mm; Nunomura and Honma 2004; Coetzee et al. 2008, 2009; Ota and Hirose 2009a, b; Ota 2011, 2014, 2015) are much larger than third praniza larvae (=finale stage larvae) of the present new species $(2.5-3.1 \mathrm{~mm})$. In the re- 
maining two species, G. camuripenis Tanaka, 2004 is distinguished from G. capitellum sp. nov. by its rectangular head, subtriangular pleotelson, peduncle articles of antennula and antenna fringed with fine setae, narrower basis of pereopods 2-4 (Tanaka 2004). Gnathia limicola Ota and Hirose, 2007 is distinguished by the triangular pleotelson with lateral margin sinuous and narrower basis of pereopods 2-4 (Ota et al. 2007). The larva of G. capitellum sp. nov. is characterized by the remarkably oval-shaped basis in the pereopods $2-4$.

Adult male of G. capitellum sp. nov. is quite unique with the small head and short mandibles. However, under the current classification of Gnathiidae, it is considered to belong to Gnathia based on the morphological features of the cephalosome and mouthparts. The genus Gnathia is the most diverse taxon in the family Gnathiidae and shows varied morphological features. Therefore, further discussions based on morphological as well as molecular data on the validity of the genus might be necessary to develop a clearer phylogenetic classification of gnathiid isopods.

\section{Acknowledgements}

The present study includes the contribution from Shimoda Marine Research Center, University of Tsukuba (SMRC). This study was supported by a joint-research in Japanese Association for Marine Biology (JAMBIO). We are indebted to Yasutaka Tsuchiya, during his previous career in SMRC, who provided host fishes. Scanning electron microscopes in this study were used in Tottori Institute of Industrial Technology. Thanks also to Dr. Chris Norman, Japan Scientific Text, who supported language supports on our manuscript. The authors thank Dr. Naoya Ohtsuchi, associate editor of Species Diversity, and two anonymous reviewers for improving manuscript and valuable comments.

\section{References}

Boyko, C. B., Bruce, N. L., Hadfield, K. A., Merrin, K. L., Ota, Y., Poore, G. C. B., Taiti, S., Schotte, M., and Wilson, G. D. F. (Eds) 2008 onwards. World Marine, Freshwater and Terrestrial Isopod Crustaceans database. Gnathiidae Leach, 1814. Available at http://www. marinespecies.org/isopoda/aphia.php? $\mathrm{p}=$ taxdetails\&id $=118278$ (31 July 2020).

Chong, Y. T., Hatai, K., and Ransangan, J. 2015. Caecognathia coralliophila (Crustacea, Isopoda, Gnathiidae) in hatchery reared tiger grouper, Epinephelus fuscogutattus, Bulletin of the European Association of Fish Pathologists 35: 177-184.

Coetzee, M. L., Smit, N. J., Grutter, A. S., and Davies, A. J. 2008. A new gnathiid (Crustacea: Isopoda) parasitizing two species of requiem sharks from Lizard Island, Great Barrier Reef, Australia. Journal of Parasitology 94: 608-615.

Coetzee, M. L., Smit, N. J., Grutter, A. S., and Davies, A. J. 2009. Gnathia trimaculata n. sp. (Crustacea: Isopoda: Gnathiidae), an ectoparasite found parasitizing requiem sharks from off Lizard Island, Great Barrier Reef, Australia. Systematic Parasitology 72: 97-112.

Cohen, B. F. and Poore, G. C. B. 1994. Phylogeny and biogeography of the Gnathiidae (Crustacea: Isopoda) with descriptions of new genera and species, most from south-eastern Australia. Memoirs of Museum of Victoria 54: 271-397.

Farquharson, C., Smit, N. J., and Sikkel, P. C. 2012. Gnathia marleyi sp. nov. (Crustacea, Isopoda, Gnathiidae) from the Eastern Caribbean. Zootaxa 3381: 47-61.

Hadfield, K. A. and Smit N. J. 2008. Description of a new gnathiid, Afrignathia multicavea gen. et sp. n. (Crustacea: Isopoda: Gnathiidae), from South Africa. African Zoology 43: 81-89.

Hadfield, K. A, Smit, N. J., and Avenant-Oldewage, A. 2009. Life cycle of the temporary fish parasite, Gnathia pilosus (Crustacea: Isopoda: Gnathiidae) from the east coast of South Africa. Journal of the Marine Biological Association of the United Kingdom 89: 13311339.

Klitgaard, A, B. 1991. Gnathia abyssorum (G. O. Sars, 1872) associated with sponges. Sarsia 76: 33-39.

Leach, W. E. 1814. Crustaceology. Brewster's Edinburgh Encylopedia 7: 383-437, pl. 221.

Monod, T. 1926. Les Gnathiidae. Mémoires de la Société des Sciences naturelles du Maroc 13: 1-668.

Mouchet, S. 1928. Note sur le cycle évolutif des Gnathiidae. Bulletin de la Société Zoologique de France 53: 392-400.

Nakabo, T. 2013. Fishes of Japan with Pictorial Keys to the Species. 3rd Edition. Tokai University Press, Hadano, 2530 pp. [In Japanese]

Nunomura, N. and Honma, Y. 2004. Gnathia capillata, a new species of the genus Gnathia (Crustacea, Isopoda) from Sado Island, the Sea of Japan. Contribution from the Biological Laboratory, Kyoto University 29: 343-349.

Ota, Y. 2011. A new species of the gnathiid isopod, Gnathia teruyukiae (Crustacea: Malacostraca), from Japan, parasitizing elasmobranch fish. Bulletin of the National Museum of Nature and Science, Series A, Supplement 5: 41-51.

Ota, Y. 2014. Three new gnathiid species with larvae ectoparasitic on coastal sharks from southwestern Japan (Crustacea: Isopoda). Zootaxa 3857: 478-500.

Ota, Y. 2015. Pigmentation patterns are useful for species identification of third-stage larvae of gnathiids (Crustacea: Isopoda) parasitising coastal elasmobranchs in southern Japan. Systematic Parasitology 90: 269-284.

Ota, Y. and Hirose, E. 2009a. Description of Gnathia maculosa and a new record of Gnathia trimaculata (Crustacea, Isopoda, Gnathiidae), ectoparasites of elasmobranchs from Okinawan coastal waters. Zootaxa 2114: 50-60.

Ota, Y. and Hirose, E. 2009b. Gnathia nubila n. sp. and a new record of Gnathia grandilaris (Crustacea, Isopoda, Gnathiidae) that parasitizes elasmobranchs from Okinawan coastal waters, Japan. Zootaxa 2238: 43-55.

Ota, Y., Tanaka, K., and Hirose, E. 2007. A new species of Gnathia (Isopoda: Cymothoida: Gnathiidae) from Okinawajima Island, Ryukyu Archipelago, southwestern Japan. Zoological Science 24: 1266-1277.

Ota, Y., Hoshino, O., Hirose, M., Tanaka, K., and Hirose, E. 2012. Third- stage larva shifts host fish from teleost to elasmobranch in the temporary parasitic isopod, Gnathia trimaculata (Crustacea; Gnathiidae). Marine Biology 159: 2333-2347.

Smit, N. J. and Davies, A. J. 2004. The curious life-style of the parasitic stages of gnathiid isopods. Advances in Parasitology 58: 289-391.

Smit, N. J., Basson, L., and Van As, J. G. 2003. Life cycle of the temporary fish parasite, Gnathia africana (Crustacea: Isopoda: Gnathiidae). Folia Parasitologica 50: 135-142.

Tanaka, K. 2003. Population dynamics of the sponge-dwelling gnathiid isopod Elaphognathia cornigera. Journal of the Marine Biological Association of the United Kingdom 83: 95-102.

Tanaka, K. 2004. A new species of Gnathia (Isopoda: Cymothoida: Gnathiidae) from Ishigaki Island, the Ryukyus, southwestern 
Japan. Crustacean Research 33: 51-60.

Tanaka, K. 2005. A new genus and species of gnathiid isopod (Isopoda, Gnathiidae) from the Ryukyus, southwestern Japan. Journal of Crustacean Biology 25: 565-569.

Tanaka, K. 2007. Life history of gnathiid isopods-current knowledge and future directions. Plankton \& Benthos Research 2: 1-11.

Tanaka, K. and Aoki, M. 1998. Crustacean infauna of the demosponge Halichondria okadai (Kabota) with reference to life cycle of Gnathia sp. (Isopoda: Gnathiidea). Pp. 259-267. In: Watanabe Y, and Fusetani, N. (Eds) Sponge Science: Multidisciplinary Perspectives. Springer, Tokyo.

Tanaka, K. and Nishi, E. 2011. Male dimorphism in the harem-forming gnathiid isopod Elaphognathia discolor (Crustacea: Isopoda). Zoo- logical Science 28: 587-592.

Wägele, J.-W. 1987. Description of the postembryonal stages of the Antarctic fish parasite Gnathia calva Vanhöffen (Crustacea: Isopoda) and synonymy with Heterognathia Amar \& Roman. Polar Biology 7: 77-92.

Wägele, J.-W. 1988. Aspects of the life-cycle of the Antarctic fish parasite Gnathia calva Vanhöffen (Crustacea: Isopoda). Polar Biology 8: 287-291.

Wilson, G. D. F., Sims, C. A., and Grutter, A. S. 2011. Toward a taxonomy of the Gnathiidae (Isopoda) using juveniles: the external anatomy of Gnathia aureamaculosa zuphea stages using scanning electron microscopy. Journal of Crustacean Biology 31: 509-522. 